\title{
Investigation of SARS-CoV-2 faecal shedding in the community: a prospective household cohort study (COVID-LIV) in the UK
}

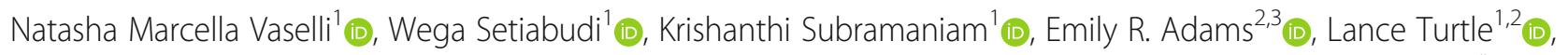
Miren Iturriza-Gómara ${ }^{1,4}$ (D) Tom Solomon ${ }^{1,2,5}$ (D) Nigel A. Cunliffe ${ }^{1,6}$ (D) Neil French ${ }^{1,2}$ (D) Daniel Hungerford ${ }^{1,2,6^{*}}$ (D) on behalf of the COVID-LIV Study Group

\begin{abstract}
Background: SARS-CoV-2 is frequently shed in the stool of patients hospitalised with COVID-19. The extent of faecal shedding of SARS-CoV-2 among individuals in the community, and its potential to contribute to spread of disease, is unknown.

Methods: In this prospective, observational cohort study among households in Liverpool, UK, participants underwent weekly nasal/throat swabbing to detect SARS-CoV-2 virus, over a 12-week period from enrolment starting July 2020. Participants that tested positive for SARS-CoV-2 were asked to provide a stool sample three and 14 days later. In addition, in October and November 2020, during a period of high community transmission, stool sampling was undertaken to determine the prevalence of SARS-CoV-2 faecal shedding among all study participants. SARS-CoV-2 RNA was detected using Real-Time PCR.

Results: A total of 434 participants from 176 households were enrolled. Eighteen participants (4.2\%: 95\% confidence interval [CI] 2.5-6.5\%) tested positive for SARS-CoV-2 virus on nasal/throat swabs and of these, 3/17 (18\%: 95\% Cl 4-43\%) had SARS-CoV-2 detected in stool. Two of three participants demonstrated ongoing faecal shedding of SARS-CoV-2, without gastrointestinal symptoms, after testing negative for SARS-CoV-2 in respiratory samples. Among 165/434 participants without SARS-CoV-2 infection and who took part in the prevalence study, none had SARS-CoV-2 in stool. There was no demonstrable household transmission of SARS-CoV-2 among households containing a participant with faecal shedding.
\end{abstract}

\footnotetext{
* Correspondence: d.hungerford@liverpool.ac.uk

'Department of Clinical Infection Microbiology and Immunology, Institute of Infection, Veterinary \& Ecological Sciences, University of Liverpool, Liverpool, UK

${ }^{2} \mathrm{NIHR}$ Health Protection Research Unit in Emerging and Zoonotic Infections at the University of Liverpool, Liverpool, UK

Full list of author information is available at the end of the article
}

(c) The Author(s). 2021 Open Access This article is licensed under a Creative Commons Attribution 4.0 International License, which permits use, sharing, adaptation, distribution and reproduction in any medium or format, as long as you give appropriate credit to the original author(s) and the source, provide a link to the Creative Commons licence, and indicate if changes were made. The images or other third party material in this article are included in the article's Creative Commons licence, unless indicated otherwise in a credit line to the material. If material is not included in the article's Creative Commons licence and your intended use is not permitted by statutory regulation or exceeds the permitted use, you will need to obtain permission directly from the copyright holder. To view a copy of this licence, visit http://creativecommons.org/licenses/by/4.0/. The Creative Commons Public Domain Dedication waiver (http://creativecommons.org/publicdomain/zero/1.0/) applies to the data made available in this article, unless otherwise stated in a credit line to the data. 
Conclusions: Faecal shedding of SARS-CoV-2 occurred among community participants with confirmed SARS-CoV-2 infection. However, during a period of high community transmission, faecal shedding of SARS-CoV-2 was not detected among participants without SARS-CoV-2 infection. It is unlikely that the faecal-oral route plays a significant role in household and community transmission of SARS-CoV-2.

Keywords: SARS-CoV-2, COVID-19, Cohort study, Faecal shedding, Transmission, Community, Asymptomatic, Gastrointestinal

\section{Background}

On January 30th 2020 the World Health Organisation (WHO) declared a public health emergency of international concern with regards to the spread of the novel virus severe acute respiratory syndrome coronavirus 2 (SARS-CoV-2), which cause COVID-19 [1].COVID-19 is a multisystem disease with the most commonly reported symptoms comprising fatigue, non-productive cough, dyspnoea and myalgia [2, 3]. Patients may also present with gastrointestinal symptoms including abdominal pain, diarrhoea, anorexia, nausea and vomiting [2-4].

Epidemiological studies have shown that transmission occurs mostly by respiratory droplets, but also via fomites and possibly via aerosols $[3,5]$. However, there is increasing evidence to suggest that the faecal-oral route could also play a role in the transmission of SARS-CoV2. Zhang et al. first isolated live SARS-CoV-2 virus from faecal samples; following inoculation of the stool suspension into Vero cells, the virus was observed under electron microscopy [6]. The presence of live virus in faecal specimens of SARS-CoV-2 infected patients has subsequently been confirmed in several studies, including from patients without gastrointestinal symptoms [7-9].

Studies in hospitalised patients have reported SARS$\mathrm{CoV}-2$ faecal shedding in up to $50 \%$ of cases [10]. A recent systematic review investigated the presence of viral RNA either in the faeces or in the intestinal cells of patients with a confirmed diagnosis of COVID-19 [11]. The systematic review included 27 studies, evaluating a total of 671 patients with laboratory-confirmed COVID19, of whom 312 (46.5\%) had a positive stool sample for viral RNA [11].

There are no published studies investigating faecal shedding in an asymptomatic or pauci-symptomatic community-based population. We have conducted a community household cohort study in Liverpool City Region, UK since July 2020, known as the COVID-LIV Study [12]. The incidence of SARS-CoV2 infection in Liverpool reached a weekly rate of 659 per 100,000 population in early-mid October 2020, with a positivity rate of $18.1 \%$ [13]. This provided an opportunity to investigate faecal shedding of SARS-CoV2 in a high incidence community setting, prior to vaccine introduction in order to better understand the role of faecal-oral transmission in disease spread, to subsequently inform the implementation of appropriate public health measures. We obtained serial stool samples from respiratory positive SARS-CoV-2 cases and undertook a two-point prevalence stool sampling investigation among COVIDLIV households.

\section{Methods \\ Study design}

The COVID-LIV Study is an observational cohort study recruiting households in the Liverpool City Region to investigate household transmission of SARS-CoV-2. Selection and recruitment of participants, along with detailed study methodology, has been described previously [12]. Briefly, participants were recruited from an established household health survey undertaken by the NIHR Collaboration for Leadership in Applied Health Research and Care (CLAHRC, now Applied Research Collaboration, ARC) and through GP surgeries and local media advertisements [14]. Enrolment of households began in July 2020; participants underwent baseline and threemonthly follow-up serological and immunological investigations, together with a weekly combined selfadministered nasal/throat swab for SARS-CoV-2, for a total of 12 weeks from enrolment. All participants were invited to complete a weekly electronic questionnaire detailing their social interactions and the presence of any symptoms of illness (Additional file 1).

\section{Stool sampling}

Participants that tested positive for SARS-CoV-2 on combined nasal/throat swabs were asked to provide a stool sample within approximately 3 days of the positive test result and 14 days later. In mid-October 2020 all households were invited by email to undertake optional stool sampling at two time points, once in October 2020 and once in November 2020. Those participants who indicated via email that they would be willing to provide a stool sample were provided with stool sampling kits. A courier picked up the stool samples within $24 \mathrm{~h}$ of the stool sample being taken and returned them to the laboratory at the University of Liverpool. Upon receipt, the stool samples were stored at $-80^{\circ} \mathrm{C}$. 


\section{Laboratory testing \\ Nasal/throat swabs}

Nasal/throat swabs were collected using eswab (Copan Diagnostics, USA) and stored at $4{ }^{\circ} \mathrm{C}$ overnight. SARSCoV-2 RNA was extracted using the Quick-DNA/RNA Viral MagBead extraction kit (Zymo Research Corp. USA).

\section{Stool samples}

The samples were thawed and approximately 200-400 $\mathrm{mg}$ of faecal material was resuspended in $1.60 \mathrm{ml}$ phosphate buffered saline (PBS) and stored at $-80^{\circ} \mathrm{C}$ until RNA extraction was undertaken. Following thawing, the faecal suspensions were vortexed for $30 \mathrm{~s}$ and $300 \mu \mathrm{l}$ was mixed 1:1 with 300 ul DNA/RNA Shield (Zymo Research Corp. USA). Samples were centrifuged at 5000 rpm for $3 \mathrm{~min}$ to pellet debris and $400 \mathrm{ul}$ of the supernatant was taken for RNA extraction, using the QuickDNA/RNA Viral MagBead extraction kit (Zymo Research Corp. USA).

\section{SARS-CoV-2 RNA detection}

SARS-CoV-2 RNA was detected using the Genesig ${ }^{\circ}$ Real-Time PCR COVID-19 (CE) assay (Primerdesign Ltd., UK), which targets the orf1 ab genome region, on a Rotor-Gene Q (Qiagen, Germany). The internal extraction control (IEC) template from the Genesig ${ }^{\bullet}$ RealTime PCR kit (Primerdesign Ltd., UK) was added to each sample prior to extraction according to manufacturer's instructions, and detected using RT-PCR. If the IEC failed the sample was re-extracted and again tested by RT-PCR. Each RT-PCR run also included a positive template control from the Genesig ${ }^{\circledR}$ Real-Time PCR kit (Primerdesign Ltd., UK). Samples with a cycle threshold (Ct) value of below 37 were considered positive. Samples with a $\mathrm{Ct}$ value between 37 and 40 were considered indeterminate and were retested in triplicate; samples were considered positive if two out of three replicates had a Ct value below 40 .

\section{Participant variables}

Participants provided demographic details, including date of birth, sex and postcode of residence. Postcode of residence was used to assign socio-economic status using English Index of Multiple Deprivation (IMD). For participants who tested positive for SARS-CoV-2 on nasal/throat swab, self-reported clinical data were obtained including symptoms at the time of positive test, medications and presence of co-morbidities.

\section{Data analysis}

Characteristics of the study cohort who provided a stool sample were compared with those that did not, by using a $\mathrm{X}^{2}$ test or Fisher's exact test for categorical variables and Wilcoxon rank sum test for continuous variables. Exact binomial 95\% confidence intervals (CIs) for proportions were calculated for SARS-CoV-2 positive participants. All analyses were conducted using $\mathrm{R}$ version 4.0.3 (R Core Team, Vienna, Austria).

\section{Results \\ Study population}

A total of 176 households including 434 participants were enrolled in the COVID-LIV Study between 9th July and 30th September 2020. Median age of participants was 46.0 (IQR: 24.3-63.0) and 53.7\% (222/434) identified as female. Of the 176 enrolled households, 17.6\% (31/ 176) were one person households, $46 \%$ (81/176) were two person households, $14.8 \%(26 / 176)$ were three person households and $21.6 \%(38 / 176)$ four of more person households. Among enrolled participants, 18/434 (4.2\%: 95\% CI 2.5-6.5) tested positive for SARS-CoV-2 on nasal/throat swab during the 12 week active follow-up period. Of these 18 SARS-CoV-2 positive cases, two were from the same household but tested positive $>6$ weeks apart, 55.6\% (10/18) were female and the median age was 42 years (range 10-72 years); 17 provided at least one stool sample (Fig. 1). Among 40\% (165/416) of SARS-CoV-2 nasal/throat swab negative participants who provided a stool sample within the two-point prevalence sampling, $53.9 \%(89 / 165)$ were female and the median age was 58 years (range $1-86$ years). Participants that took part in the prevalence stool sampling were more likely to be older $(p<0.001)$ and from less socioeconomically deprived IMD deciles $(p<0.001)$ than those that did not take part (Table 1) There was no difference in sex between the two groups of participants ( $p=0.912$; Table 1$)$. A total of 153 participants provided a sample during the October 2020 sampling period and 135 in the November 2020 sampling period; 123 participants provided stools samples at both time points (Fig. 1).

SARS-CoV-2 nasal/throat swab PCR positive participants

All PCR positive cases occurred between August and October 2020 , with the majority $(77.8 \% ; 14 / 18)$ of the cases occurring before the peak of SARS-CoV-2 infection in the Liverpool City Region (Fig. 2). Five of the cases $(27.8 \%)$ tested positive for SARS-CoV-2 on two or more consecutive nasal/throat swabs. Cases were from a variety of household sizes ranging from one to four occupants. Six cases $(33.3 \%)$ were asymptomatic and three cases $(16.7 \%)$ reported gastrointestinal symptoms including diarrhoea, nausea and vomiting. None of the cases was hospitalised in the 2 weeks following the first nasal/ throat swab positive result. All cases reported no comorbidities. 


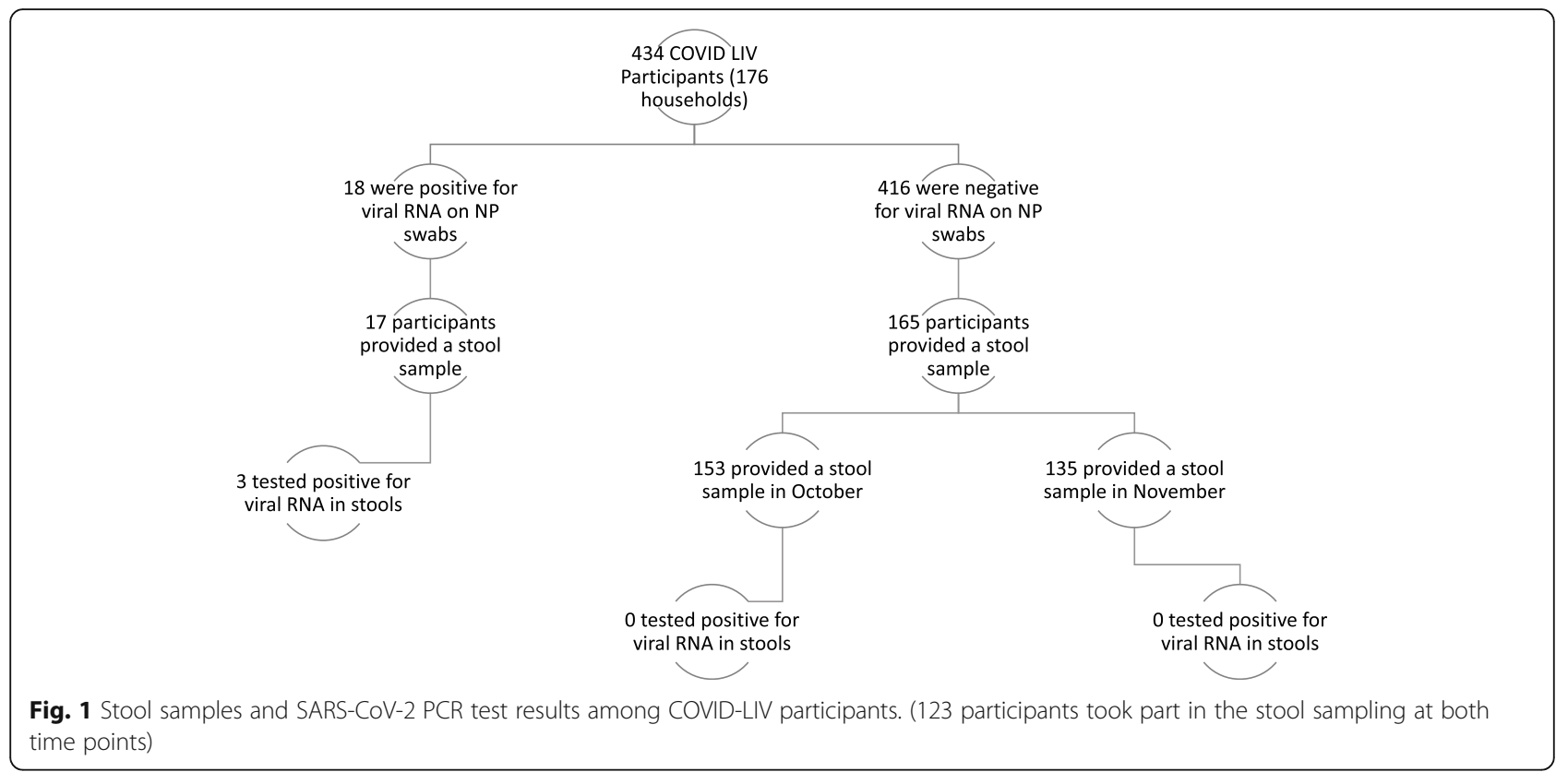

SARS-CoV-2 faecal shedding among nasal/throat swab PCR positive participants

Three of the 17 participants who provided a stool sample had SARS-CoV-2 RNA detected (18\%: 95\% CI 4$43 \%)$. The three participants with faecal shedding included a male aged 15-19 years (four person household; two household members aged 50-54 years and one aged 15-19 years), a female aged 15-19 years (two person household; other household member aged 55-59 years) and 50-54 year old male (three person household;

Table 1 Characteristics of COVID-LIV participants

\begin{tabular}{|c|c|c|c|c|c|}
\hline \multirow[t]{2}{*}{ Characteristics } & \multicolumn{4}{|c|}{ SARS-CoV-2 nasal/ throat swab negative participants } & \multirow{2}{*}{$\begin{array}{l}\text { SARS-CoV-2 } \\
\text { nasal/ throat } \\
\text { swab positive } \\
\text { participants } \\
(N=18)\end{array}$} \\
\hline & $\begin{array}{l}\text { No stool provided } \\
(N=251)\end{array}$ & $\begin{array}{l}\text { Stool provided } \\
(N=165)\end{array}$ & $\begin{array}{l}\text { Overall } \\
(N=416)\end{array}$ & $P$ value & \\
\hline IMD & & & & $<0.001$ & \\
\hline 1 (most deprived) & $70(27.9 \%)$ & $25(15.2 \%)$ & $95(22.8 \%)$ & & $5(27.8 \%)$ \\
\hline 2 & $32(12.7 \%)$ & $15(9.1 \%)$ & $47(11.3 \%)$ & & $3(16.7 \%)$ \\
\hline 3 & $15(6.0 \%)$ & $14(8.5 \%)$ & $29(7.0 \%)$ & & $<3$ \\
\hline 4 & $30(12.0 \%)$ & $16(9.7 \%)$ & $46(11.1 \%)$ & & $<3$ \\
\hline 5 & $22(8.8 \%)$ & $15(9.1 \%)$ & $37(8.9 \%)$ & & $<3$ \\
\hline 6 & $24(9.6 \%)$ & $25(15.2 \%)$ & $49(11.8 \%)$ & & $<3$ \\
\hline 7 & $12(4.8 \%)$ & $15(9.1 \%)$ & $27(6.5 \%)$ & & $<3$ \\
\hline 8 & $18(7.2 \%)$ & $23(13.9 \%)$ & $41(9.9 \%)$ & & $<3$ \\
\hline 9 & $17(6.8 \%)$ & $3(1.8 \%)$ & $20(4.8 \%)$ & & $<3$ \\
\hline 10 (least deprived) & $11(4.4 \%)$ & $14(8.5 \%)$ & $25(6.0 \%)$ & & $<3$ \\
\hline \multicolumn{6}{|l|}{ Age } \\
\hline Median IQR [Min, Max] & $15 / 39 / 57[1,82]$ & $42 / 58 / 66[1,86]$ & $24 / 46 / 63[1,86]$ & $<0.001$ & $26 / 42 / 61[10,72]$ \\
\hline \multicolumn{6}{|l|}{ Sex } \\
\hline Female & $134(53.4 \%)$ & $89(53.9 \%)$ & $223(53.6 \%)$ & 0.912 & $10(55.6 \%)$ \\
\hline Male & $117(46.6 \%)$ & $76(46.1 \%)$ & $193(46.4 \%)$ & & $8(44.4 \%)$ \\
\hline
\end{tabular}

The $P$ value compares those who provided a stool sample and those who did not in the SARS-CoV-2 nasal/throat swab negative population IMD refers to the English Index of Multiple Deprivation deciles, assigned based on patient postcode IQR refers to the interquartile range

$<3$ refers to numbers suppressed to prevent participant disclosure 


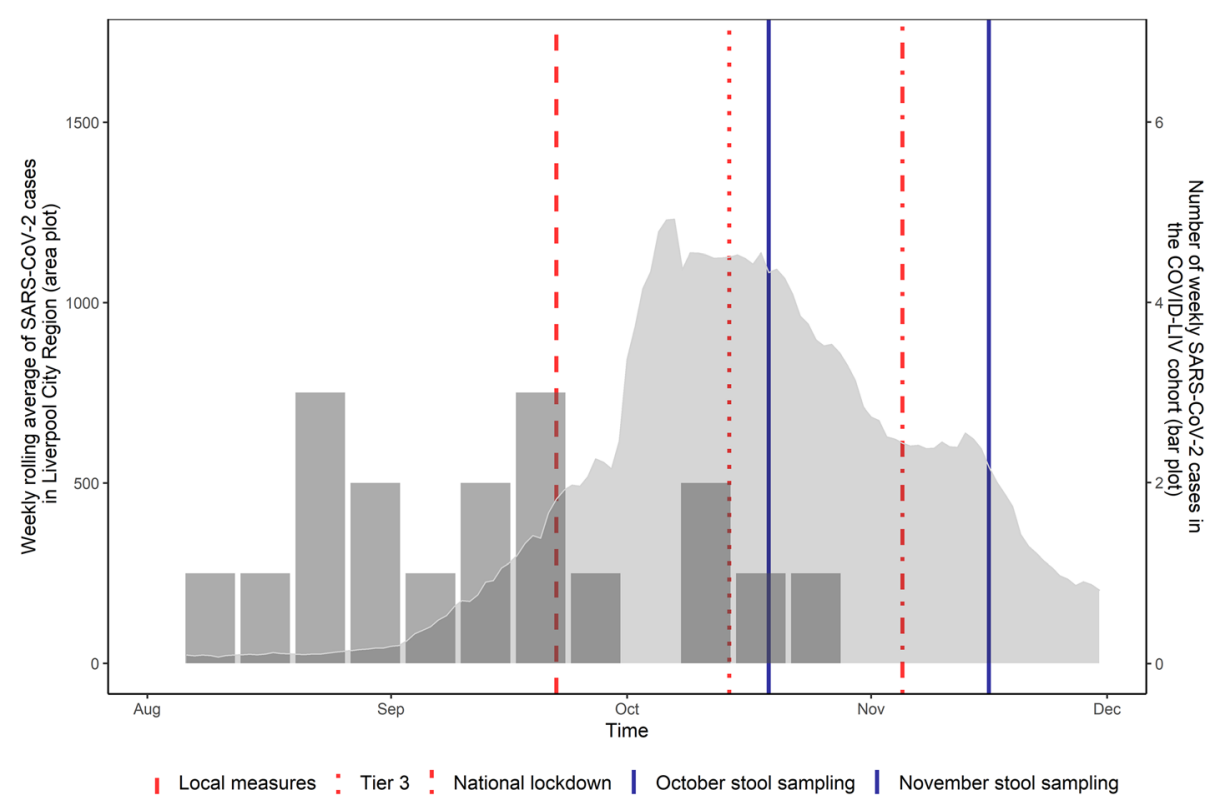

Fig. 2 Background rate of SARS-CoV-2 cases in the Liverpool City Region in relation to the timing of COVID-LIV cases, stool sampling and public health measures. (SARS-CoV-2 case data for the Liverpool City Region adapted from https://coronavirus.data.gov.uk/details/download [accessed 09/12/2020])

Table 2 Features of SARS-CoV-2 nasal/throat swab PCR positive COVID-LIV participants

\begin{tabular}{|c|c|c|c|c|c|c|}
\hline$\overline{I D^{a}}$ & $\begin{array}{l}\text { Nasal/throat swab } \\
\text { positive (first test } \\
\text { is day } 1 \text { ) }\end{array}$ & $\begin{array}{l}\text { Nasal/throat } \\
\text { Ct values }\end{array}$ & $\begin{array}{l}\text { Nasal/throat Swab } \\
\text { negative (days since } \\
\text { first positive nasal/ } \\
\text { throat swab) }\end{array}$ & $\begin{array}{l}\text { Stool samples (days } \\
\text { since first positive } \\
\text { nasal/throat swab) }\end{array}$ & $\begin{array}{l}\text { Stool positive (days } \\
\text { since first positive } \\
\text { nasal/throat swab) }\end{array}$ & $\begin{array}{l}\text { Stool Ct } \\
\text { values }\end{array}$ \\
\hline$a-002$ & 1 & 35.00 & 7 & $5,49,78$ & Negative & $\mathrm{N} / \mathrm{A}$ \\
\hline b-001 & 1 & 35.49 & 15 & $8,23,71,86$ & Negative & N/A \\
\hline$c-002$ & 1 & 35.69 & 14 & $6,21,69,98$ & Negative & N/A \\
\hline$d-002$ & 1,6 & $33.87,35.11$ & 15 & 8,16 & 8,16 & $20.00,33.03$ \\
\hline e-002 & 1 & 35.28 & 6 & 7,20 & Negative & N/A \\
\hline$f-001$ & 1 & 35.01 & 7 & 8,18 & Negative & N/A \\
\hline g-001 & 1 & 34.41 & 7 & $6,20,28$ & Negative & N/A \\
\hline h-003 & $1,5,7$ & $22.13,32.65,28.05$ & 14 & 6 & Negative & N/A \\
\hline $\mathrm{i}-002$ & 1 & 36.79 & 6 & 7,15 & Negative & N/A \\
\hline j-001 & 1 & 35.60 & 7 & 4,15 & Negative & N/A \\
\hline k-002 & 1 & 27.07 & 6 & 6,18 & Negative & N/A \\
\hline I-002 & 1 & 36 & 12 & $6,13,23$ & Negative & N/A \\
\hline $\mathrm{m}-003$ & $1,8,14$ & $32.90,28.52,34.07$ & 21 & 6,19 & Negative & $\mathrm{N} / \mathrm{A}$ \\
\hline n-003 & 1 & 30.78 & 6 & $6,17,34,61$ & Negative & N/A \\
\hline $0-003$ & 1,7 & $16.40,35.48$ & 14 & 21 & 21 & 23.66 \\
\hline p-002 & 1,7 & $19.18,33.14$ & NA & 4 & 4 & 33.46 \\
\hline$q-001$ & 1 & 30.62 & 6 & 7,14 & Negative & N/A \\
\hline$r-003$ & 1 & 31.70 & 6 & NA & N/A & N/A \\
\hline
\end{tabular}

Random anonymous ID 
other household members aged 50-54 years and 20-24 years); none reported gastrointestinal symptoms. None of the three faecal shedders took any regular medications. The $\mathrm{Ct}$ values for the stool samples ranged from 20.00-33.46; of the three participants who faecally shed viral RNA, two had among the lowest Ct values (highest viral load) on the nasal/throat swabs (16.40 and 19.18), and one participant tested positive on repeat nasal/ throat swabbing (Table 2). Two out of the three participants had detectable virus in stool beyond the time that respiratory samples tested negative for viral RNA (Table 2). One participant tested positive for viral RNA in the stool at 16 days, and the other participant at 21 days after a nasal/throat swab positive test for SARSCoV-2 virus; they continued to shed in their stools for three and 7 days respectively after testing PCR negative on nasal/ throat swab. There was no transmission within the households of those who tested positive for viral RNA in stool.

\section{Faecal shedding of SARS-CoV-2 among nasal/throat swab PCR negative participants}

None of the 165 participants that tested negative for SARS-CoV-2 RNA in the upper respiratory tract had viral RNA detected in their stool samples in either October or November 2020.

\section{Discussion}

To our knowledge this is the first reported communitybased study investigating faecal shedding of SARS-CoV2 . The overall rate of faecal shedding in this community was low; while 3/17 participants who tested positive for SARS-CoV-2 on nasal/throat swab showed evidence of faecal shedding, 0/165 participants that were negative for SARS-CoV-2 on nasal/throat showed evidence of viral RNA in their stools when sampled over two time points.

In comparison to the relatively low rate of faecal shedding among respiratory PCR positive subjects reported here, studies conducted in hospital settings have reported faecal shedding in up to $50 \%$ of patients with COVID-19 [10]. This could potentially be due to differences in the severity of symptoms, viral load in the respiratory tract, or in the propensity of the virus to disseminate, which post-mortem evidence suggests happens in patients who have died from severe COVID-19 [15]. However, our study showed that participants with both high and low $\mathrm{Ct}$ values in respiratory material shed the virus faecally. Moreover, a recent study showed no difference in the duration of viral shedding, or in SARSCoV-2 load, in stool samples among patients with mild or severe disease [16]. This highlights that other factors other than viral load are likely to be involved in the faecal shedding of SARS-CoV-2.
Faecal shedding in this study was not associated with the presence of gastrointestinal symptoms. Previous studies of faecal shedding in patients who were asymptomatic or had mild symptoms of SARS-CoV-2 infection also demonstrated a lack of association between faecal shedding and gastrointestinal symptoms [4, 17-20]. However, several hospital-based studies found that gastrointestinal symptoms, in particular diarrhoea, were associated with faecal shedding [21-23]. Moreover, those with gastrointestinal symptoms had a longer duration between symptom onset and viral clearance [21]. A recent study investigated the intestinal microbiota in SARS-CoV-2 hospitalised patients with GI manifestations. This study found that patients with prolonged GI manifestations had a reduction in the diversity and richness in their microbiota and prolonged viral clearance [24]. Studies report that the relative abundance of the microbiota Coprobacillus, Clostridium ramosum, and Clostridium hathewayi positively correlated to COVID19 severity [25]. Furthermore, studies have shown that ACE-2 receptor is the entry point for SARS-CoV-2 virus into the gastrointestinal tract [26]. The interaction between the ACE-2 receptor and SARS-CoV-2 can lead to receptor dysregulation, intestinal inflammation and the manifestation of gastrointestinal symptoms [25]. Differences in the expression of the ACE-2 receptor in the gastrointestinal tract could explain differences in faecal shedding and gastrointestinal symptoms among individuals with SARS-CoV-2 infection.

Two out of three participants that had viral RNA detected in their stools demonstrated persistent faecal shedding despite negative nasal/throat swabs for SARSCoV-2. Previous studies in hospitalised patients have demonstrated prolonged faecal shedding for up to 5 weeks after respiratory samples were negative for viral RNA, including one study which showed that $80 \%$ of children had persistent positive real time RT- PCR test of rectal swabs [19, 27, 28].

Persistent faecal shedding of SARS-CoV-2 may potentially allow faecal-oral transmission. However, within our study there was no transmission of infection within the households of participants who had detectable viral RNA in their stools. Furthermore, in the two-point prevalence stool sampling none of the participants had detectable SARSCoV-2 RNA in stool, despite sampling being undertaken during a period of high transmission of SARS-CoV-2 in the community. Together, our data do not suggest a significant role for faecal-oral transmission in the community. Additionally, our findings have implications for the utility of rectal swabs for COVID-19 diagnosis and public health surveillance, and for the use of wastewater for surveillance of SARS-CoV-2 $[8,29]$. A number of the participants, particularly those younger and from more socioeconomically deprived neighbourhoods, did not provide faecal samples. 
This further suggests that the use of rectal swabs could produce partial, and systematically biased data.

\section{Limitations}

Participant engagement in the two-point prevalence stool sampling was low. Only 40\% (165/416) of enrolled, respiratory PCR negative participants provided a stool sample; participants providing a stool sample were slightly older and less deprived than the remainder of the COVID-LIV population. This highlights the difficulty of undertaking stool surveillance in the community, even among our research-engaged study population. Additionally, as faecal shedding appears more common in children compared with adults, we may have underestimated shedding in the respiratory negative participants $[27,28]$. We also did not obtain enough serial stool samples to determine cessation of faecal shedding. Furthermore, for mucosal pathogens such as SARS-CoV-2, relating PCR detection of viral nucleic acid in clinical samples to infectiousness remains problematic. Finally, during the study period there were few strains of the SARS-CoV-2 virus in circulation. Since December 2020, there has been an increase in the alpha (B.1.1.7; first detected in the UK) variant in the UK which has spread globally and from May 2021 the delta (B.1.617.2; first detected in India) variant $[30,31]$. As new strains emerge it is important to investigate the propensity of these new variants to be associated with faecal shedding, and the consequent role of faecal-oral transmission in virus spread.

\section{Conclusion}

In this community household cohort study, faecal shedding of SARS-CoV-2 viral RNA was detected among respiratory positive participants. However, in two-point prevalence stool sampling conducted during an intense period of community transmission, we did not detect SARS-CoV-2 viral RNA in the stool of SARS-CoV-2 respiratory negative participants. Our study demonstrates that faecal shedding of SARS-CoV-2 is unlikely to play a significant role in transmission of infection in households and in the community.

\section{Abbreviations \\ ARC: Applied Research Collaboration; Cl: Confidence interval; IMD: Index of Multiple Deprivation; NHS: National Health Service; PCR: Polymerase Chain Reaction; RNA: Ribose Nucleic Acid; RT-PCR: Reverse transcription Polymerase Chain Reaction; SARS-CoV-2: Severe acute respiratory syndrome coronavirus 2; SD: Standard deviation; UK: United Kingdom; WHO: World Health Organisation}

\section{Supplementary Information}

The online version contains supplementary material available at https://doi. org/10.1186/s12879-021-06443-7.

Additional file 1.

\section{Acknowledgments}

The authors would like to thank and appreciate all the participants in the study for their invaluable contribution and to Debbie Howarth, Eve Wilcock, Claudia McKeown and Chris Williams for processing the stool samples. We would also like to acknowledge support in study set-up and delivery, from the National Institute for Health Research Clinical Research Network, North West Coast, Chris Smith (Chief Operating Officer) and Philippa Tubb, Managing Director Well Travelled Clinics Ltd., Liverpool School of Tropical Medicine.

The following are members of the COVID-LIV Study Group: Principal investigator: Neil French.

Study Investigators: Lance Turtle, Daniel Hungerford, Krishanthi Subramaniam, Roberto Vivancos, Mark Gabbay, lain Buchan, Enitan D. Carrol, Miren Iturriza-Gómara, Tom Solomon, Nigel A. Cunliffe, Emily R. Adams, Carrol Gamble.

Lay members: Lynnette Crossley, Neil Joseph.

Fieldwork team: Wega Setiabudi, Natasha Marcella Vaselli, Moon Wilton, Lee

D. Troughton, Samantha Kilada, Katharine Abba, Victoria Simpson, John S.P.

Tulloch, Lynsey Goodwin, Rachael Daws, Shiva Seyed Forootan, Susan

Dobson, Rachel Press, Vida Spaine, Lesley Hands, Kate Bradfield, Carol McNally.

Project management: Tracy Moitt, Silviya Balabanova, Chloe Donohue, Lynsey Finnetty, Laura Marsh.

Clinical and laboratory team: William Greenhalf, Dean J. Naisbitt, Victoria E. Shaw, Stephen Aston, Gareth Platt, Christopher Dunn, Paul J. Thomson, Monday Ogese, Sean Hammond, Kareena Adair, Liam Farrell, Joshua Gardner, Kanoot Jaruthamsophon, Serat-E Ali, Adam Lister, Laura Booth, Milton Ashworth, Katie Bullock, Benjamin W.A. Catterall, Terry Foster, Lara LavelleLangham, Joanna Middleton, William Reynolds, Emily Cass, Alejandra Doce Carracedo, Lianne Davies, Lisa Flaherty, Melanie Oates, Nicole Maziere, Jennifer Lloyd, Christopher Jones, Hannah Massey, Anthony Holmes, Nicola Carlucci, Vanessa Brammah, Yasmyn Ramos, Daniel Allen, Jane Armstrong, Debbie Howarth, Eve Wilcock, Jenna Lowe, Jayne Jones, Paula Wright, lain Slack, Simone McLaughlin, Jessica Mason, Thomas Edwards, Claudia McKeown, Elysse Hendrick, Chris Williams, Rachel Byrne, Kate Buist, Gala Garrod, Sophie Owen.

Statisticians: Ashley P. Jones, Efstathia Gkioni.

\section{Authors' contributions}

DH, NAC, NF, LT, ERA and MIG conceptualised and designed the study and were responsible for supervision. TS conceptualised and designed the study. $\mathrm{DH}, \mathrm{WS}, \mathrm{NMV}$, and KS were responsible for collection, accessing and verifying the data. ERA and diagnostic team were responsible for sample testing. NMV, WS and DH were responsible visualisation, formal analysis and for writing the original draft. All authors reviewed and edited the manuscript. The authors read and approved the final manuscript.

\section{Funding}

This study is co-funded by the National Institute for Health Research Health Protection Research Unit (NIHR HPRU) in Gastrointestinal Infections, a partnership between Public Health England, the University of Liverpool and the University of Warwick; the NIHR HPRU in Emerging and Zoonotic Infections, a partnership between Public Health England, the University of Liverpool in collaboration with the Liverpool School of Tropical Medicine and the University of Oxford; the Centre of Excellence in Infectious Disease Research (CEID R); and the Alder Hey Charity. Grant number for the funding is not applicable.

NF is funded by the NIHR HPRU in Emerging and Zoonotic Infections, the CEIDR and the Alder Hey Charity. We also acknowledge the support of Liverpool Health Partners and the Liverpool-Malawi-Covid-19 Consortium. LT is supported by a Wellcome Trust fellowship (205228/Z/16/Z). For the purpose of Open Access, the author has applied a CC BY public copyright licence to any Author Accepted Manuscript version arising from this submission. WS is funded by the Ministry of Finance, the Republic of Indonesia through the Indonesia Endowment Fund for Education (Lembaga Pengelola Dana Pendidikan or LPDP) scholarship for doctoral study (201807220413052). DH is funded by an NIHR Postdoctoral Fellowship (PDF2018-11-ST2-006). KS is funded by a HEFCE-funded University of Liverpool Tenure Track Fellowship. LT is also supported by the NIHR HPRU in Emerging and Zoonotic Infections (NIHR200907). 
The views expressed are those of the authors and not necessarily those of the NHS, the NIHR, the Department of Health and Social Care, PHE or other funding bodies. The study funders had no role in study design, data collection, data analysis, data interpretation or writing of the manuscript.

\section{Availability of data and materials}

After completion of the full COVID-LIV study de-identified participant data will be made available to others for meta-analysis upon request following Study Steering Group discussion and signing of a data access agreement. Requests for access to data should be made to the corresponding author via the corresponding email given.

\section{Declarations}

\section{Ethics approval and consent to participate}

The study has received approval from the NHS Research Ethics Committee; REC Reference: 20/HRA/2297, IRAS Number: 283464. Protocol amendments have been to the Research Ethics Committee. The study participants provided written informed consent and are informed that all data collected are for research purposes only and that they have the right to withdraw from the study at any time.

\section{Consent for publication}

Not applicable.

\section{Competing interests}

NF reports research grant support from the Alder Hey Charity. MIG reports other financial or non-financial interests in V-PLEX Th17 Panel 1 Human Kit. LT reports research grant support from NIHR HPRU in Emerging and Zoonotic Infections related to this study. Unrelated to this study LT also reports fees paid to University of Liverpool from Eisai for providing a lecture on COVID-19 and cancer. WS reports scholarship for doctoral study at the University of Liverpool from the Ministry of Finance, Republic of Indonesia through the Indonesia Endowment Fund for Education program. DH, NAC, ERA, TS, KS and NMV have nothing to disclose.

\section{Author details}

${ }^{1}$ Department of Clinical Infection Microbiology and Immunology, Institute of Infection, Veterinary \& Ecological Sciences, University of Liverpool, Liverpool, UK. ${ }^{2} \mathrm{NIHR}$ Health Protection Research Unit in Emerging and Zoonotic Infections at the University of Liverpool, Liverpool, UK. ${ }^{3}$ Department of Tropical Disease Biology, Liverpool School of Tropical Medicine, Liverpool, UK. ${ }^{4}$ Current address: Centre for Vaccine Innovation and Access, PATH, Geneva, Switzerland. ${ }^{5}$ Walton Centre NHS Foundation Trust, Liverpool, UK. ${ }^{6} \mathrm{NIHR}$ Health Protection Research Unit in Gastrointestinal Infections at the University of Liverpool, Liverpool, UK

\section{Received: 7 May 2021 Accepted: 20 July 2021}

Published online: 09 August 2021

\section{References}

1. World Health Organization (WHO). Timeline of WHO's response to COVID19. https://www.who.int/emergencies/diseases/novel-coronavirus-2019/ interactive-timeline\#!. Accessed 2020 Nov 1.

2. Wang D, Hu B, Hu C, Zhu F, Liu X, Zhang J, et al. Clinical characteristics of 138 hospitalized patients with 2019 novel coronavirus-infected pneumonia in Wuhan, China. JAMA. 2020;323(11):1061-9. https://doi.org/10.1001/jama.2 020.1585 .

3. Wiersinga WJ, Rhodes A, Cheng AC, Peacock SJ, Prescott HC. Pathophysiology, transmission, diagnosis, and treatment of coronavirus disease 2019 (COVID-19). JAMA. 2020;324(8):782-93. https://doi.org/10.1001/ jama.2020.12839.

4. Lin L, Jiang X, Zhang Z, Huang S, Zhang Z, Fang Z, et al. Gastrointestinal symptoms of 95 cases with SARS-CoV-2 infection. Gut. 2020;69(6):997-1001. https://doi.org/10.1136/gutjnl-2020-321013.

5. Hui DSC, Zumla A. Severe acute respiratory syndrome: historical, epidemiologic, and clinical features. Infect Dis Clin N Am. 2019;33(4):869-89. https://doi.org/10.1016/j.idc.2019.07.001.

6. Zhang Y, Chen C, Zhu S, Shu C, Wang D, Song J, et al. Isolation of 2019$\mathrm{nCoV}$ from a stool specimen of a laboratory-confirmed case of the coronavirus disease 2019 (COVID-19). China CDC Wkly. 2020;2(8):123-4. https://doi.org/10.46234/ccdcw2020.033.

7. Wang W, Xu Y, Gao R, Lu R, Han K, Wu G, et al. Detection of SARS-CoV-2 in different types of clinical specimens. JAMA. 2020;323(18):1843-4. https://doi. org/10.1001/jama.2020.3786.

8. Bwire GM, Majigo MV, Njiro BJ, Mawazo A. Detection profile of SARS-CoV-2 using RT-PCR in different types of clinical specimens: a systematic review and meta-analysis. J Med Virol. 2021;93(2):719-25. https://doi.org/10.1002/ jmv.26349.

9. D'Amico F, Baumgart DC, Danese S, Peyrin-Biroulet L. Diarrhea during COVID-19 infection: pathogenesis, epidemiology, prevention, and management. Clin Gastroenterol Hepatol. 2020;18(8):1663-72. https://doi. org/10.1016/j.cgh.2020.04.001.

10. Ong J, Young BE, Ong S. COVID-19 in gastroenterology: a clinical perspective. Gut. 2020;69(6):1144-5. https://doi.org/10.1136/gutjnl-2020-321051.

11. Cuicchi D, Lazzarotto T, Poggioli G. Fecal-oral transmission of SARS-CoV-2: review of laboratory-confirmed virus in gastrointestinal system. Int J Color Dis. 2021;36(3):437-44. https://doi.org/10.1007/s00384-020-03785-7.

12. Setiabudi $W$, Hungerford $D$, Subramaniam $K$, et al. Prospective observational study of SARS-CoV-2 infection, transmission and immunity in a cohort of households in Liverpool City region, UK (COVID-LIV): a study protocol. BMJ Open. 2021;11:48317.

13. Liverpool City Council Corprate Intelligence Team. Liverpool COVID-19 report. 2020 https://iverpool.gov.uk/media/1359761/14102020_external.pdf. Accessed 29 Mar 2021

14. Giebel C, Mclntyre JC, Daras K, et al. What are the social predictors of accident and emergency attendance in disadvantaged neighbourhoods? Results from a cross-sectional household health survey in the north west of England. BMJ Open. 2019;9(1):e022820. https://doi.org/10.1136/bmjopen-201 8-022820.

15. Dorward DA, Russell CD, Um IH, Elshani M, Armstrong SD, Penrice-Randal R, et al. Tissue-specific immunopathology in fatal COVID-19. Am J Respir Crit Care Med. 2021;203(2):192-201. https://doi.org/10.1164/rccm.202008-32 $650 C$.

16. Zheng S, Fan J, Yu F, et al. Viral load dynamics and disease severity in patients infected with SARS-CoV-2 in Zhejiang province, China, Januarymarch 2020: retrospective cohort study. BMJ. 2020;369:m1443. https://doi. org/10.1136/bmj.m1443.

17. Park S-K, Lee C-W, Park D-I, Woo HY, Cheong HS, Shin HC, et al. Detection of SARS-CoV-2 in fecal samples from patients with asymptomatic and mild COVID-19 in Korea. Clin Gastroenterol Hepatol. 2020;19(7):1387-1394.e2. https://doi.org/10.1016/j.cgh.2020.06.005.

18. Hua C, Miao Z, Zheng J, et al. Epidemiological features and viral shedding in children with SARS-CoV-2 infection. J Med Virol. 2020;92(11):2804-12. https://doi.org/10.1002/jmv.26180.

19. Wu Y, Guo C, Tang $L$, et al. rolonged presence of SARS-CoV-2 viral RNA in faecal samples. Lancet Gastroenterol Hepatol. 2020;5(5):434-5.

20. Chen $Y$, Chen L, Deng Q, Zhang G, Wu K, Ni L, et al. The presence of SARSCoV-2 RNA in the feces of COVID-19 patients. J Med Virol. 2020;92(7):83340. https://doi.org/10.1002/jmv.25825.

21. Han C, Duan C, Zhang S, Spiegel B, Shi H, Wang W, et al. Digestive symptoms in COVID-19 patients with mild disease severity: clinical presentation, stool viral RNA testing, and outcomes. Am J Gastroenterol. 2020;115(6):916-23. https://doi.org/10.14309/ajg.0000000000000664.

22. Wei X-S, Wang X, Niu Y-R, et al. Diarrhea Is associated with prolonged symptoms and viral carriage in corona virus disease 2019. Clin Gastroenterol Hepatol. 2020;18(8):1753-1759.e2.

23. Holshue ML, DeBolt C, Lindquist S, Lofy KH, Wiesman J, Bruce H, et al. First case of 2019 novel coronavirus in the United States. N Engl J Med. 2020; 382(10):929-36. https://doi.org/10.1056/NEJMoa2001191.

24. Gu S, Chen Y, Wu Z, Chen Y, Gao H, Lv L, et al. Alterations of the gut microbiota in patients with coronavirus disease 2019 or H1N1 influenza. Clin Infect Dis. 2020;71(10):2669-78. https://doi.org/10.1093/cid/ciaa709.

25. Lelis G, De Oliveira V, Narjara C, et al. Microbiota modulation of the gut-lung Axis in COVID-19. Front Immunol. 2021;12. https://doi.org/10.3389/fimmu.2 021.635471.

26. Liang W, Feng Z, Rao S, Xiao C, Xue X, Lin Z, et al. Diarrhoea may be underestimated: a missing link in 2019 novel coronavirus. Gut. 2020;69(6): 1141-3. https://doi.org/10.1136/gutjnl-2020-320832.

27. Xu Y, Li X, Zhu B, Liang H, Fang C, Gong Y, et al. Characteristics of pediatric SARS-COV-2 infection and potential evidence for persistent fecal viral 
shedding. Nat Med. 2020;26(4):502-5. https://doi.org/10.1038/s41591-020$0817-4$.

28. Xing Y, Ni W, Wu Q, et al. Prolonged presence of SARS-CoV-2 in feces of pediatric patients during the convalescent phase. medRxiv. 2020. https://doi. org/10.1101/2020.03.11.20033159.

29. Larsen DA, Wigginton KR. Tracking COVID-19 with wastewater. Nat Biotechnol. 2020;38(10):1151-3. https://doi.org/10.1038/s41587-020-0690-1.

30. McNally A. What makes new variants of SARS-CoV-2 concerning is not where they come from, but the mutations they contain. BMJ. 202;372:n504. https://doi.org/10.1136/bmj.n504.

31. Wise J. Covid-19: Exponential growth in infections in England is driven by young people BMJ 2021;373:n1568. https://doi.org/10.1136/bmj.n1568.

\section{Publisher's Note}

Springer Nature remains neutral with regard to jurisdictional claims in published maps and institutional affiliations.

Ready to submit your research? Choose BMC and benefit from:

- fast, convenient online submission

- thorough peer review by experienced researchers in your field

- rapid publication on acceptance

- support for research data, including large and complex data types

- gold Open Access which fosters wider collaboration and increased citations

- maximum visibility for your research: over $100 \mathrm{M}$ website views per year

At BMC, research is always in progress.

Learn more biomedcentral.com/submissions 